\title{
Persepsi Petani tentang Peranan Penyuluh dalam Peningkatan Produksi Padi di Kecamatan Tabir Kabupaten Merangin Provinsi Jambi
}

\section{Perceptions of Farmers on the Role of Extensioners in Increasing Rice Production In District of Tabir Regency Merangin Jambi Province}

\author{
Padillah $^{1}$, Ninuk Purnaningsih ${ }^{2}$, Dwi Sadono ${ }^{2}$ \\ ${ }^{1}$ Program Studi Pascasarjana Ilmu Penyuluhan Pembangunan, Fakultas Ekologi Manusia, Institut Pertanian Bogor, Bogor \\ ${ }^{2}$ Departemen Sains Komunikasi dan Pengembangan Masyarakat, Fakultas Ekologi Manusia, \\ Institut Pertanian Bogor, Bogor
}

\begin{abstract}
Rice is the main source of food and the government is obliged to realize its availability and fulfillment. This study aims to: (1) analyze the perception of farmers about the role of extension workers in increasing rice production; and (2) to analyze the factors that influence farmers ' perceptions about the role of extension workers in increasing rice production. This research used survey method and executed in March until May 2017 in District of Tabir Regency Merangin Jambi Province. The sample size of this study is 92 people. The analytical method used is descriptive statistics and inferential statistics (Path Analysis) which is equipped with qualitative data. The result of the research shows that: (1) the perception of farmers about the role of extension agent in increasing the rice production is good enough, the extension agent has enough role and has done its role according to the main task and its function in the Special Rice, Corn, and Soy Special Efforts program; and (2) factors that directly affect farmers' perceptions about the role of extension agents in increasing rice production are the extent of land tenure, and the intensity of the farmer's interaction with the extension worker.
\end{abstract}

Keywords: perception, extension agent role, production rice increase

\begin{abstract}
Abstrak
Padi merupakan sumber pangan paling utama dan pemerintah berkewajiban mewujudkan ketersediaan serta pemenuhannya. Penelitian ini bertujuan untuk: (1) menganalisis tingkat persepsi petani tentang peranan penyuluh dalam peningkatan produksi padi; dan (2) menganalisis faktor-faktor yang mempengaruhi tingkat persepsi petani tentang peranan penyuluh dalam peningkatan produksi padi. Penelitian ini menggunakan metode survei dan dilaksanakan pada bulan Maret hingga Mei 2017 di Kecamatan Tabir Kabupaten Merangin Provinsi Jambi. Jumlah sampel penelitian ini adalah 92 orang. Metode analisis yang digunakan adalah statistik deskriptif dan statistik inferensial (Path Analysis) yang dilengkapi dengan data kualitatif. Hasil penelitian menunjukkan bahwa: (1) tingkat persepsi petani tentang peranan penyuluh dalam peningkatan produksi padi sudah cukup baik, berarti penyuluh sudah cukup berperan dan sudah menjalankan peranannya sesuai dengan tugas pokok dan fungsinya di dalam program Upaya Khusus Padi, Jagung, dan Kedelai; dan (2) faktor yang berpengaruh secara langsung terhadap tingkat persepsi petani tentang peranan penyuluh dalam peningkatan produksi padi adalah luas penguasaan lahan, dan intensitas interaksi petani dengan penyuluh.
\end{abstract}

Kata kunci: persepsi, peranan penyuluh, peningkatan produksi padi

\section{Pendahuluan}

Produksi padi nasional pada tahun 2015 sejumlah 75,55 juta ton gabah kering giling (Kementan, 2016) dan jumlah penduduk Indonesia 255,46 juta jiwa (BPS, 2014a) dengan konsumsi beras 114 kg/orang pertahun perkapita (BPS, 2014b). Jumlah tersebut sudah mencukupi untuk memenuhi kebutuhan konsumsi pangan masyarakat di Indonesia, namun distribusi antar daerah belum merata yang disebabkan oleh infrastruktur yang tidak merata dan sulitnya akses untuk mencapai daerah-daerah terpencil. Oleh karena itu perlu upaya untuk peningkatan produksi dan produktivitas padi di setiap daerah yang salah satunya dilaksanakan di Kabupaten Merangin Provinsi Jambi.

Kabupaten Merangin memiliki potensi dalam pengembangan sektor pertanian tanaman pangan khususnya padi. Produksi padi di Kabupaten tersebut merupakan salah satu yang terbesar di Provinsi Jambi dengan jumlah 107,107 ton yang tersebar di 24 kecamatan. Saat ini tanaman padi di Kabupaten Merangin mengalami peningkatan antara lain produksi 
sebesar 92,89\%, produktivitas sebesar 6,66 \% dan luas tanam sebesar 45,43\% dari tahun 2015 (Dinas Pertanian Tanaman Pangan dan Hortikultura Kabupaten Merangin, 2016). Keberhasilan ini merupakan serangkaian kerja sama antara pihak pemerintah pusat dan pemerintah daerah, tetapi tentunya tidak terlepas dari peranan penting penyuluh yang bersentuhan langsung dengan petani. Berdasarkan hal tersebut dapat diduga bahwa penyuluh sudah menjalankan tugas dan fungsinya, namun belum diketahui apakah peranan penyuluh tersebut sudah sesuai dengan harapan petani sebagai penerima manfaat dari kegiatan penyuluhan, oleh sebab itu perlu diketahui bagaimana pandangan petani terhadap peranan penyuluh dalam upaya peningkatan produksi padi karena penyuluh merupakan seseorang yang bersentuhan langsung dengan petani.

Pandangan individu setelah adanya proses penafsiran terhadap suatu objek setelah adanya stimulasi disebut dengan persepsi (Rivai dan Mulyadi, 2012). Hasil penelitian Anggreany et al. (2015) menemukan bahwa persepsi petani terhadap inovasi replanting menilai cukup menguntungkan dan cukup mudah diamati hasil penerapannya, namun dikatakan cukup rumit untuk diterapkan sesuai dengan anjuran pemerintah. Persepsi yang terbentuk dalam diri petani dapat mempengaruhi cara pandangnya terhadap peranan penyuluh. Jumlah penyuluh di Kabupaten Merangin saat ini berjumlah 167 penyuluh pertanian, yang terdiri dari 119 penyuluh PNS dan 48 penyuluh THL-TBPP (Tenaga Harian Lepas Tenaga Bantu Penyuluh Pertanian). Jika dilihat dari jumlah desa/kelurahan binaan yang ada yaitu sebanyak 215 desa/kelurahan, ini berarti jumlah penyuluh pertanian di Kabupaten Merangin belum sesuai amanah Undang-Undang Republik Indonesia No. 16 tahun 2006 yaitu satu desa satu penyuluh sehingga memungkinkan peranan penyuluh pertanian belum optimal.

Penyuluh di dalam kegiatan penyuluhan merupakan faktor pelancar pembangunan (Mosher, 1978). Layaknya faktor pelancar dalam sukses pembangunan pertanian jika ia tidak berperan maka faktor pelancar yang lain akan sulit untuk bergerak. Hal ini sejalan dengan hasil penelitian Riana et al. (2015) bahwa peranan penyuluh selain berperan dalam membantu peningkatan produksi dan produktivitas kakao juga sebagai pemberi motivasi, dukungan dan membantu petani dalam memecahkan masalah. Mardikanto dan Soebiato (2013) menyatakan bahwa penyuluh adalah sebagai jembatan penghubung antara pemerintah atau lembaga penyuluhan yang di wakilinya baik dalam penyampaian inovasi maupun kebijakan-kebijakan serta menyampaikan umpan balik dari masyarakat yang bertujuan membantu masyarakat memperbaiki mutu hidup dan kesejahteraannya. Hal ini juga dikuatkan dalamUURINo. 16 tahun 2006 mengenai fungsi penyuluh pertanian sebagai fasilitator kegiatan pembelajaran, mempermudah akses informasi dan teknologi, pengembangan kemampuan kepemimpinan, menumbuhkan kesadaran terhadap kelestarian fungsi lingkungan hidup, dan mengembangkan organisasinya sehingga memiliki daya saing.

Kebutuhan konsumsi pangan khususnya masyarakat di Provinsi Jambi semakin meningkat. Hal ini merupakan dampak dari semakin bertambahnya jumlah penduduk dan berkurangnya lahan pertanian/ sawah sebagai akibat dari terjadinya alih fungsi lahan untuk kepentingan pembangunan. Berdasarkan hal tersebut pemerintah Provinsi Jambi membuat program strategis yang bertujuan untuk pengembangan pertanian khususnya padi, jagung, dan kedelai guna mencapai masyarakat Provinsi Jambi dapat mandiri pangan dan berswasembada pangan yang salah satunya dilaksanakan di Kabupaten Merangin. Seluruh kegiatan yang tergabung dalam budidaya padi di Kabupaten Merangin di danai dari Dana APBN-P Ditjen Prasarana dan Sarana Kementrian Pertanian. Penanggungjawab kegiatan penyuluhan pada sektor pertanian tanaman pangan di Kabupaten Merangin adalah Badan Pelaksana Penyuluhan, Pertanian, Perikanan dan Kehutanan (BP4K) yang kini sudah bergabung dengan Dinas Pertanian Tanaman Pangan dan Hortikultura sejak tanggal 1 Januari 2017.

Untuk mewujudkan itu semua peran serta dan keterlibatan penyuluh di lapangan tentu sangat dibutuhkan. Sejarah telah membuktikan hasil gemilang atas program dan motivasi yang tinggi serta kerja keras para penyuluh dalam mendukung keberhasilan pembangunan pertanian yang telah mengantarkan bangsa Indonesia dalam pencapaian swasembada beras pada tahun 1984 melalui program BIMAS (Bimbingan Massal). Program upaya khusus padi, jagung, dan kedelai (Upsus Pajale) tidak akan mencapai tujuan dengan baik tanpa persepsi positif dari petani terhadap peranan penyuluh dan partisipasi aktif dari petani itu sendiri. Petani pada prinsipnya harus diposisikan sebagai subyek atau aktor utama karena sebagai penerima manfaat dari program Upsus Pajale. Oleh karena itu perlu dilakukan penelitian tentang persepsi petani tentang peranan penyuluh dalam peningkatan produksi padi 
pada program Upsus Pajale. Peranan penyuluh dalam upaya peningkatan produksi padi dalam penelitian ini ialah sesuai dengan peranan penyuluh dalam Permentan No. 14/Permentan/OT.140/3/2015 tentang Pedoman Pengawalan dan Pendampingan Upsus Pajale. Tujuan penelitiaan ini adalah (1) menganalisis tingkat persepsi petani tentang peranan penyuluh dalam peningkatan produksi padi; dan (2) menganalisis faktor-faktor yang mempengaruhi tingkat persepsi petani tentang peranan penyuluh dalam peningkatan produksi padi.

\section{Metode Penelitian}

Penelitian ini menggunakan metode survei dengan analisis statistik deskriptif dan statistik inferensial (Path analysis) yang dilengkapi dengan data kualitatif. Lokasi penelitian dilakukan di 8 desa/kelurahan di Kecamatan Tabir Kabupaten Merangin Provinsi Jambi pada bulan Maret hingga Mei 2017. Populasi penelitian adalah petani yang mengikuti program Upsus Pajale dan tergabung dalam kelompoktani yang dibina oleh penyuluh PNS/THL-TBPP sebanyak 1.139 orang.

Penarikan sampel dilakukan dengan menggunakan rumus Slovin (Riduwan danAkdon, 2009) secara proportional simple random sampling yaitu 92 orang yang diambil dari dua orang pengurus (ketua dan atau sekretaris) dan sisanya dari anggota kelompoktani dari setiap desa/kelurahan. Menurut Muljono (2012) teknik pengambilan sampel menggunakan random sampling memberikan peluang yang sama kepada setiap anggota populasi untuk terpilih menjadi sampel. Uji validitas dan uji reliabilitas dilakukan pada 30 orang non sampel di Desa Telagasari Kabupaten Karawang Provinsi Jawa Barat. Hasil uji validitas nilai $r$ hitungnya berkisar antara 0,393 hingga 0,949, sedangkan hasil uji reliabilitas nilai cronbachs alphanya berkisar antara 0,740 hingga 0,764 .

Variabel bebas (eksogen) dalam penelitian ini adalah karakteristik petani yang terdiri dari: umur, tingkat pendidikan formal, jumlah tanggungan keluarga, lama berusahatani, status penguasaan lahan, luas penguasaan lahan, dan tingkat pengetahuan petani tentang peranan penyuluh. Interaksi petani dengan penyuluh dan kelompok terdiri dari: intensitas interaksi petani dengan penyuluh, dan keterlibatan dalam kelompoktani. Variabel terikat (endogen) dalam penelitian ini adalah tingkat persepsi petani tentang peranan penyuluh dalam peningkatan produksi padi.

Pengujian variabel dalam penelitian ini menggunakan Path Analysis yang bertujuan untuk melihat pola hubungan antar variabel dengan tujuan untuk mengetahui pengaruh langsung maupun tidak langsung seperangkat variabel bebas (eksogen) terhadap variabel terikat (endogen) (Riduwan dan Kuncoro, 2014). Nilai koefisien jalur yang digunakan adalah hasil dari uji regresi linier berganda menggunakan Aplikasi SPSS (Statistical Package for the Social Science) versi 21.

\section{Hasil dan Pembahasan}

\section{Gambaran Umum Lokasi Penelitian}

Kecamatan Tabir merupakan salah satu kecamatan di Kabupaten Merangin, Provinsi Jambi, Indonesia. Kecamatan Tabir terdiri dari 6 desa dan 5 kelurahan yang memiliki luas wilayah $242 \mathrm{Km}^{2}$ dan ketinggian 68 sampai dengan 135 meter di atas permukaan laut (mdpl) dengan batas administratif yaitu: sebelah utara berbatasan dengan Kabupaten Bungo,

Tabel 1. Jumlah Sebaran Sampel di Kecamatan Tabir Kabupaten Merangin pada Tahun 2017

\begin{tabular}{clcccr}
\hline No. & \multicolumn{1}{c}{ Desa/kelurahan } & Populasi (orang) & $\begin{array}{c}\text { Sampel } \\
\text { (orang) }\end{array}$ & $\begin{array}{c}\text { Sampel } \\
\text { pengurus }\end{array}$ & $\begin{array}{c}\text { Sampel } \\
\text { anggota }\end{array}$ \\
\hline 1 & Dusun Baru & 327 & 26 & 2 & 24 \\
2 & Pasar Rantau Panjang & 68 & 6 & 2 & 4 \\
3 & Kampung Baruh & 69 & 6 & 2 & 4 \\
4 & Mampun & 94 & 8 & 2 & 6 \\
5 & Beluran Panjang & 116 & 9 & 2 & 7 \\
6 & Seling & 276 & 22 & 2 & 20 \\
7 & Tanjung Ilir & 92 & 7 & 2 & 5 \\
8 & Lubuk Napal & 97 & 8 & 2 & 6 \\
\hline Jumlah & 1.139 & 92 & 16 & 76 \\
\hline
\end{tabular}


sebelah barat berbatasan dengan Kecamatan Tabir Ulu, sebelah selatan berbatasan dengan Kecamatan Tabir Selatan dan Kecamatan Tabir Ilir, dan sebelah timur berbatasan dengan Kecamatan Tabir Selatan dan Kecamatan Tabir Ilir.

Berdasarkan data BPS Kabupaten Merangin tahun 2016 penduduk di Kecamatan Tabir berjumlah 29.446 jiwa. Terdapat 14.800 jiwa penduduk lakilaki dan 14.646 penduduk perempuan. Jarak tempuh Kecamatan Tabir dengan ibukota kabupaten yaitu 35 $\mathrm{Km}$. Komoditi yang diusahakan oleh masyarakat di Kecamatan Tabir terdiri dari komoditi tanaman pangan, hortikultura, dan perkebunan rakyat. Komoditi tanaman pangan pada tahun 2014 terdiri dari padi sawah seluas 1.810 hektar, padi gogo seluas 364,7 hektar, jagung seluas 34,5 hektar, dan kedelai seluas 30,9 hektar (Unit Pelaksana Teknis Daerah (UPTD) Pertanian Kecamatan Tabir, 2014).

Gambaran Umum Penyuluh Pertanian di Kecamatan Tabir

Wilayah kerja UPTD Pertanian Kecamatan Tabir meliputi wilayah kerja Kecamatan Tabir yang beribukota di Kelurahan Pasar Rantau Panjang dan Kecamatan Tabir Ulu yang beribukota di Desa Rantau Limau Manis. UPTD Kecamatan Tabir secara geografis terletak pada titik koordinat $01^{\circ} 50$ '28,4" dan $102^{\circ} 18^{\prime} 02,2^{\prime \prime}$ dengan luas wilayah 25.819 hektar. Ketenagakerjaan penyuluh di UPTD Pertanian wilayah kerja Kecamatan Tabir terdapat 16 penyuluh, terdiri dari: penyuluh PNS/CPNS pertanian sebanyak 9 orang yang yaitu 7 orang penyuluh pertanian, 1 orang penyuluh perikanan, dan 1 orang penyuluh kehutanan. Penyuluh THL-TBPP sebanyak 1 orang, penyuluh honorer daerah 1 orang, dan penyuluh swadaya 5 orang yaitu membantu penyuluh pertanian.

Kelembagaan petani yang tercatat pada UPTD Pertanian wilayah kerja Kecamatan Tabir pada tahun 2014 adalah 71 kelompoktani dengan tingkat kemampuan: 12 kelompok golongan BDK (Belum Dikukuhkan), 17 kelompok golongan pemula, 30 kelompok golongan lanjut, 12 kelompok golongan madya kemudian terdapat 11 Gapoktan (Gabungan Kelompoktani), 1 Pokdakan (Kelompok Pembudidaya Ikan), 11 Posluhdes (Pos Penyuluh Desa/Kelurahan), 11 KTNA (Kelompoktani Nelayan Andalan) dan 1 Pos IPAH (Informasi Pelayanan Agen Hayati) (UPTD Pertanian Kecamatan Tabir, 2014).

\section{Karakteristik Petani}

Karakteristik petani dalam penelitian ini terdiri dari umur, tingkat pendidikan formal, jumlah tanggungan keluarga, lama berusahatani, status penguasaan lahan, luas penguasaan lahan, dan tingkat pengetahuan petani tentang peranan penyuluh. Deskripsi dari masingmasing karakteristik petani dijelaskan lebih lanjut pada Tabel 2. Umur responden sebagian besar berada pada kategori muda $(45,65 \%)$ dan diikuti pada kategori dewasa (42,39\%) yang berada antara 27-72 tahun. Menurut BPS (2016) sebagian usia tersebut (27-64 tahun) tergolong usia produktif. Dari segi kesehatan dan kemampuan bekerja responden dengan usia produktif mempunyai kemampuan bekerja dan beraktivitas yang lebih tinggi dibandingkan dengan yang sudah tidak produktif.

Tingkat pendidikan formal responden dalam penelitian ini yang rendah mulai dari tidak sekolah hingga hanya kelas $5 \mathrm{SD}$, sementara tingkat pendidikan yang tergolong tinggi mencapai perguruan tinggi yaitu hingga Strata 1 (S-1). Tingkat pendidikan formal responden sebagian besar berada pada kategori sedang $(56,52 \%)$. Hal ini disebabkan sulitnya mendapatkan biaya pendidikan dan rendahnya kesadaran serta peran orang tua jaman dahulu untuk menyekolahkan anaknya hingga ke jenjang yang lebih tinggi. Sebagian besar responden berpendapat bahwa dengan keadaan yang demikian lebih memilih tidak melanjutkan pendidikan melainkan bekerja sejak umur masih sangat muda untuk membantu perekonomian keluarga.

Jumlah tanggungan keluarga dalam penelitian ini berkisar antara 1-13 orang. Jumlah tanggungan keluarga responden terbesar berada pada kategori sedikit (78,26\%), namun tanggungan yang dimiliki (anak) masih bersekolah sehingga masih memerlukan biaya dan belum dapat membantu dalam kegiatan usahatani padi sawah. Pengalaman berusahatani responden berada antara 3-37 tahun, persentase terbesar berada pada kategori lama (48,91\%) dan diikuti pada kategori muda $(43,48 \%)$. Petani yang sudah lama berusahatani akan lebih mudah untuk menerapkan inovasi dari pada petani pemula, hal ini dikarenakan pengalaman yang lebih banyak sehingga sudah dapat membuat perbandingan dalam mengambil keputusan (Mardikanto, 1993).

Status kepemilikan lahan sebagian besar berada pada kategori milik sendiri $(71,73 \%)$ dengan rata-rata luas lahan satu hektar. Pemilik tanah dengan status milik sendiri mempunyai pengawasan yang lebih lengkap atas 
Tabel 2. Jumlah dan Persentase Petani berdasarkan Karakteristiknya di Kecamatan Tabir pada Tahun 2017

\begin{tabular}{|c|c|c|c|}
\hline Karakteristik petani & Kategori & Jumlah (orang) & Persen $(\%)$ \\
\hline $\begin{array}{l}\operatorname{Umur}\left(\mathrm{X}_{1 \cdot 1}\right) \\
\text { Rataan }=45\end{array}$ & $\begin{array}{l}\text { Muda (27-43) } \\
\text { Dewasa (44-59) } \\
\text { Tua }(60-76)\end{array}$ & $\begin{array}{l}42 \\
39 \\
11\end{array}$ & $\begin{array}{l}45,65 \\
42,39 \\
11,96\end{array}$ \\
\hline $\begin{array}{l}\text { Tingkat pendidikan formal }\left(\mathrm{X}_{1 \cdot 2}\right) \\
\text { Rataan }=7\end{array}$ & $\begin{array}{l}\text { Rendah }(0-5) \\
\text { Sedang }(6-10) \\
\text { Tinggi }(11-16)\end{array}$ & $\begin{array}{l}23 \\
52 \\
17\end{array}$ & $\begin{array}{l}25,00 \\
56,52 \\
18,48\end{array}$ \\
\hline $\begin{array}{l}\text { Jumlah tanggungan keluarga }\left(\mathrm{X}_{1 \cdot 3}\right) \\
\text { Rataan }=3\end{array}$ & $\begin{array}{l}\text { Sedikit }(0-3) \\
\text { Sedang }(4-7) \\
\text { Banyak }(8-13)\end{array}$ & $\begin{array}{r}72 \\
18 \\
2\end{array}$ & $\begin{array}{r}78,26 \\
19,57 \\
2,17\end{array}$ \\
\hline $\begin{array}{l}\text { Lama berusahatani }\left(\mathrm{X}_{1 \cdot 4}\right) \\
\text { Rataan }=15\end{array}$ & $\begin{array}{l}\text { Baru (3-14) } \\
\text { Lama (15-25) } \\
\text { Sangat Lama (26-37) }\end{array}$ & $\begin{array}{r}40 \\
45 \\
7\end{array}$ & $\begin{array}{r}43,48 \\
48,91 \\
7,61\end{array}$ \\
\hline $\begin{array}{l}\text { Status penguasaan lahan }\left(\mathrm{X}_{1 \cdot 5}\right) \\
\text { Rataan= milik sendiri }\end{array}$ & $\begin{array}{l}\text { Bagi hasil } \\
\text { Sewa } \\
\text { Gilir } \\
\text { Milik sendiri }\end{array}$ & $\begin{array}{r}6 \\
2 \\
18 \\
66\end{array}$ & $\begin{array}{r}6,52 \\
2,17 \\
19,56 \\
71,73\end{array}$ \\
\hline $\begin{array}{l}\text { Luas penguasaan lahan }\left(\mathrm{X}_{1 \cdot 6}\right) \\
\text { Rataan }=1 \text { ha }\end{array}$ & $\begin{array}{l}\text { Sempit }(0,25 \text { ha }-1 \text { ha }) \\
\text { Sedang }(1,01 \text { ha }-1,75 \text { ha }) \\
\text { Luas }(1,78-3 \text { ha })\end{array}$ & $\begin{array}{r}86 \\
4 \\
2\end{array}$ & $\begin{array}{r}93,48 \\
4,35 \\
2,17\end{array}$ \\
\hline $\begin{array}{l}\text { Tingkat pengetahuan petani tentang } \\
\text { peranan penyuluh }\left(\mathrm{X}_{1 \cdot 7}\right)\end{array}$ & $\begin{array}{l}\text { Rendah }(0-33,33) \\
\text { Sedang }(33,34-66,66) \\
\text { Tinggi }(66,67-100)\end{array}$ & $\begin{array}{l}59 \\
19 \\
14\end{array}$ & $\begin{array}{l}64,13 \\
20,65 \\
15,22\end{array}$ \\
\hline
\end{tabular}

pelaksanaan usahataninya, bila dibandingkan dengan petani yang status lahannya bagi hasil. Para pemilik dapat membuat keputusan untuk mengadopsi inovasi sesuai dengan keinginannya.

Luas lahan responden berkisar antara 0,25 hektar hingga 5 hektar. Luas penguasaan lahan terbanyak berada pada kategori sempit $(93,48 \%)$ yang luasnya berkisar antara 0,25 hektar hingga 1 hektar. Petani yang memiliki atau menguasai lahan di bawah 0,5 hektar dikatakan dengan petani gurem. Kepemilikan lahan rata-rata di bawah 0,5 hektar dan tanpa ditopang adanya manajemen pengelolaan lahan yang memungkinkan tercapainya skala usaha, akan mengakibatkan usahatani menjadi kurang menarik secara ekonomis, karena tidak dapat memberikan jaminan sebagai sumber pendapatan yang mampu memberikan penghidupan yang layak (Sastraatmadja, 2006).

Tingkat pengetahuan petani tentang peranan penyuluh yang sesuai dengan petunjuk pelaksanaan kegiatan program Upsus Pajale terbesar berada pada kategori rendah $(64,13 \%)$. Hal ini disebabkan oleh rata-rata petani yang dibina oleh penyuluh masih belum mengetahui keseluruhan tugas dan fungsi sebenarnya dari seorang penyuluh di dalam program Upsus Pajale. Sebagian besar responden menganggap bahwa tugas dan fungsi penyuluh hanya membantu di dalam kegiatan budidaya padi sawah, serta membantu mereka ketika mempunyai masalah dan mencarikan solusinya karena penyuluh dianggap seseorang yang dapat langsung berkomunikasi dengan pihak pemerintah dalam hal ini UPTD Pertanian.

\section{Interaksi Petani dengan Penyuluh dan Kelompok}

Tabel 3 menyajikan data tentang intensitas interaksi petani dengan penyuluh dan keterlibatan dalam kelompotani. Intensitas interaksi petani dengan penyuluh terbesar berada pada kategori rendah $(96,74$ \%). Mata pencaharian masyarakat di Kecamatan Tabir didominasi oleh petani kebun karet dan kebun sawit, hal ini menyebabkan petani sudah sangat sibuk sehingga pekerjaan sebagai petani padi sering dianggap sebagai pekerjaan sampingan.

Interakasi petani dengan penyuluh sering 
terjadi saat kunjungan penyuluh ke lokasi program Upsus Pajale (sawah atau saung) secara langsung yang biasanya dilaksanakan sesuai dengan jadwal yaitu hari selasa hingga dengan hari jumat, sedangkan pada hari senin biasanya penyuluh mengadakan pertemuan rutin dengan UPTD pertanian Kecamatan Tabir. Penyuluh bisanya datang ke lokasi untuk mengecek kondisi sawah dan untuk mendengarkan keluhan petani jika terdapat kendala di dalam program tersebut. Selain di sawah dan saung interaksi petani dengan penyuluh juga sering terjadi pada saat pertemuan kelompok, di rumah dan melalui telepon. Interaksi yang terjadi dirumah dan melalui telepon biasanya interaksi antara ketua/pengurus dengan penyuluh saja.

Tabel 3. Jumlah dan Persentase Petani berdasarkan Interaksinya dengan Penyuluh dan Kelompok di Kecamatan Tabir pada tahun 2017

\begin{tabular}{|c|c|c|c|}
\hline $\begin{array}{c}\text { Interaksi petani } \\
\text { dengan penyuluh } \\
\text { dan kelompok }\end{array}$ & Kategori & $\begin{array}{l}\text { Jumlah } \\
\text { (orang) }\end{array}$ & $\begin{array}{c}\text { Persen } \\
(\%)\end{array}$ \\
\hline \multirow{3}{*}{$\begin{array}{l}\text { Intensitas } \\
\text { interaksi petani } \\
\text { dengan penyuluh } \\
\left(\mathrm{X}_{2 \cdot 1}\right)\end{array}$} & $\begin{array}{l}\text { Rendah } \\
(10-20)\end{array}$ & 89 & 96,74 \\
\hline & $\begin{array}{l}\text { Sedang } \\
(21-30)\end{array}$ & 1 & 1,09 \\
\hline & $\begin{array}{l}\text { Tinggi } \\
(31-40)\end{array}$ & 2 & 2,17 \\
\hline \multirow{3}{*}{$\begin{array}{l}\text { Keterlibatan } \\
\text { dalam } \\
\text { kelompoktani } \\
\left(\mathrm{X}_{2 \cdot 2}\right)\end{array}$} & $\begin{array}{l}\text { Rendah } \\
(0-6)\end{array}$ & 18 & 19,57 \\
\hline & $\begin{array}{l}\text { Sedang } \\
(7-12)\end{array}$ & 58 & 63,04 \\
\hline & $\begin{array}{l}\text { Tinggi } \\
(13-20)\end{array}$ & 16 & 17,39 \\
\hline
\end{tabular}

Keterlibatan dalam kelompoktani sebagian besar mengikuti kurang dari dua belas kali pertemuan yaitu berada pada kategori sedang $(63,04 \%)$. Hal ini dikaranakanpetanidilokasipenelitiandalamberusahatani padi sawah bukanlah sebagai mata pencaharian utama, sehingga ada sebagian kelompoktani yang mengadakan pertemuan rutin jika hanya berada dalam masa tanam padi dan waktunyapun tidak ditentukan hanya berdasarkan kesepakatan dan kebutuhan. Pertemuan diadakan untuk membahas berbagai rencana kegiatan seperti pelaksanaan, evaluasi, dan masalah anggota yang berkaitan dengan kegiatan usahatani padi.

Permasalahan dalam berusahatani yang sering dibahas saat pertemuan adalah tentang hama dan penyakit serta pasca panen yang biasanya dilaksanakan di saung yang terdapat di dekat sawah. Rata-rata durasi pertemuan yang dilaksanakan antara 2-4 jam tergantung permasalahan yang dihadapi oleh petani. Semakin sulit permasalahannya maka akan semakin lama waktu pertemuannya. Penyuluh di dalam pertemuan kelompok melakukan komunikasi secara terbuka dengan anggota kelompoktani dengan harapan anggota kelompoktani dapat berkomunikasi dengan nyaman dan terbuka pula dengan penyuluh. Kelompoktani di Kecamatan Tabir yang mengikuti program Upsus Pajale ialah sebanyak 48 kelompoktani

\section{Tingkat Persepsi Petani tentang Peranan Penyuluh dalam Peningkatan Produksi Padi}

Tabel 4 menyajikan data tentang tingkat persepsi petani tentang peranan penyuluh dalam peningkatan produksi padi yang terbesar berada pada kategori sedang $(70,65 \%)$. Hal ini menunjukkan bahwa peranan penyuluh di dalam peningkatan produksi padi sudah cukup berperan dan sudah menjalankan peranannya sesuai dengan tugas pokok dan fungsinya di dalam program Upsus Pajale. Namun petani masih beranggapan bahwa penyuluh dalam berkomunikasi masih dalam pendekatan individu yaitu dengan ketua kelompok dan pengurus saja, sehingga masih banyak informasi-informasi yang tidak sampai kepada anggota kelompoktani. Tingkat persepsi petani tentang peranan penyuluh dalam peningkatan produksi padi dalam penelitian ini terdiri dari perencanaan GP-PTT, pelaksanakan GP-PTT, dan POL yang berada pada kategori sedang yang berarti penyuluh sudah cukup berperan, sedangkan RJIT dan PAT berada pada ketegori rendah yang berarti penyuluh belum berperan.

Hal ini bertentangan dengan hasil penelitian Fauzi dan Sadono (2006) bahwa persepsi masyarakat sasaran terhadap manfaat program PUKK (Pengembangan Usaha Kelompok Kecil) tergolong tinggi, karena dengan harapan program PUKK mampu meningkatkan pendapatan mereka yang berpengaruh pada perkembangan perekonomian masyarakat Kecamatan Nanggung. Rendahnya tingkat persepsi petani tentang peranan penyuluh di dalam RJIT dikarenakan penyuluh kurang berperan di dalam penentuan perbaikan jaringan irigasi, penentuan calon teknisi, pembagian air, dan mengecek jaringan irigasi yang telah diperbaiki. Peranan penyuluh di dalam PAT juga rendah dikarenakan penyuluh kurang berperan di 
Tabel 4. Jumlah dan Persentase Petani berdasarkan Tingkat Persepsinya tentang Peranan Penyuluh dalam Peningkatan Produksi Padi di Kecamatan Tabir pada Tahun 2017

\begin{tabular}{|c|c|c|c|}
\hline Tingkat persepsi petani & Kategori & $\begin{array}{l}\text { Jumlah } \\
\text { (orang) }\end{array}$ & Persen \\
\hline $\begin{array}{l}\text { Persepsi petani tentang peranan penyuluh dalam perencanaan } \\
\text { GP-PTT }\end{array}$ & $\begin{array}{l}\text { Rendah } \\
\text { Sedang } \\
\text { Tinggi }\end{array}$ & $\begin{array}{l}33 \\
45 \\
14\end{array}$ & $\begin{array}{l}35,87 \\
48,91 \\
15,22\end{array}$ \\
\hline $\begin{array}{l}\text { Persepsi petani tentang peranan penyuluh dalam pelaksanaan } \\
\text { GP-PTT }\end{array}$ & $\begin{array}{l}\text { Rendah } \\
\text { Sedang } \\
\text { Tinggi }\end{array}$ & $\begin{array}{r}5 \\
68 \\
19\end{array}$ & $\begin{array}{r}5,43 \\
73,91 \\
20,65\end{array}$ \\
\hline $\begin{array}{l}\text { Persepsi petani tentang peranan penyuluh dalam Percepatan } \\
\text { Optimalisasi Lahan (POL) }\end{array}$ & $\begin{array}{l}\text { Rendah } \\
\text { Sedang } \\
\text { Tinggi }\end{array}$ & $\begin{array}{l}11 \\
45 \\
36\end{array}$ & $\begin{array}{l}11,96 \\
48,91 \\
39,13\end{array}$ \\
\hline $\begin{array}{l}\text { Persepsi petani tentang peranan penyuluh dalam Rehabilitasi } \\
\text { Jaringan Irigasi Tersier (RJIT) }\end{array}$ & $\begin{array}{l}\text { Rendah } \\
\text { Sedang } \\
\text { Tinggi }\end{array}$ & $\begin{array}{l}59 \\
23 \\
10\end{array}$ & $\begin{array}{l}64,13 \\
25,00 \\
10,87\end{array}$ \\
\hline $\begin{array}{l}\text { Persepsi petani tentang peranan penyuluh dalam Penambahan } \\
\text { Areal Tanam (PAT) }\end{array}$ & $\begin{array}{l}\text { Rendah } \\
\text { Sedang } \\
\text { Tinggi }\end{array}$ & $\begin{array}{l}43 \\
28 \\
21\end{array}$ & $\begin{array}{l}46,74 \\
30,43 \\
22,83\end{array}$ \\
\hline $\begin{array}{l}\text { Persepsi petani tentang peranan penyuluh dalam peningkatan } \\
\text { produksi padi (total) }\end{array}$ & $\begin{array}{l}\text { Rendah } \\
\text { Sedang } \\
\text { Tinggi }\end{array}$ & $\begin{array}{l}16 \\
65 \\
11\end{array}$ & $\begin{array}{l}17,39 \\
70,65 \\
11,96\end{array}$ \\
\hline
\end{tabular}

Keterangan: Rendah (0-33,33), Sedang (33,34-66,66), Tinggi (66,67-100)

dalam mendampingi petani pada saat penambahan areal tanam padi, dan memberikan petunjuk untuk menanam padi dalam kegiatan usahatani yang akan dilakukan oleh petani pada waktu mendatang.

Peranan penyuluh dalam perencanaan GPPTT sudah cukup baik dalam mendampingi perwakilan UPTD Pertanian pada pendataan dan penetapan calon petani serta calon lokasi untuk program Upsus Pajale, kemudian peranan penyuluh dalam pelaksanaan GPPTT sudah cukup baik yang dimulai dari pengolahan tanah hingga pemanenan dan paling paling berperan dalam mendampingi petani pada saat penanaman serentak dengan menggunakan sistem tanam jajar legowo. Peranan penyuluh dalam POL juga sudah cukup baik pada pembagian dan pengecekan benih, pupuk, dan pestisida. Selain terlibatnya penyuluh di dalam kegiatan penyampaian sarana produksi dibantu oleh Babinsa (Bintara Pembina Desa) dan perwakilan dari UPTD pertanian untuk mengecek dan pembagian benih, pupuk, dan obat-obatan agar sampai ke petani tepat pada waktunya dan tepat sasaran.

Perbaikan jaringan irigasi dilaksanakan di setiap desa/kelurahan di lokasi penelitian kecuali,
Kelurahan Pasar Rantau Panjang. Hal ini dikarenakan pihak pemerintah dari kabupaten memilih lokasi-lokasi yang sangat membutuhkan perbaikan irigasi tersebut. Penambahan areal tanam di lokasi penelitian selain dilakukan oleh petani itu sendiri juga dibantu oleh Babinsa yang dilaksanakan di setiap desa/kelurahan di lokasi penelitian kecuali Kelurahan Mampun dan Kelurahan Kampung Baruh. Hal ini dikarenakan lokasi tersebut sudah dipadati oleh rumah penduduk dan kebun karet sehingga tidak ada lahan untuk menambah areal tanam padi.

\section{Analisis Jalur Faktor-Faktor yang Mempengaruhi Tingkat Persepsi Petani tentang Peranan Penyuluh dalam Peningkatan Produksi Padi}

Peranan penyuluh di dalam suatu program sangat berperan penting guna sebagai jembatan penghubung antara pemerintah serta menyampaikan umpan balik dari masyarakat yang bertujuan membantu masyarakat memperbaiki mutu hidup dan kesejahteraannya. Keberhasilan suatu program tidak akan tercapai dengan baik tanpa persepsi positif dari 
Tabel 5. Pengaruh Langsung Karakteristik Petani dan Interaksi Petani dengan Penyuluh dan Kelompok terhadap Tingkat Persepsi Petani tentang Peranan Penyuluh dalam Peningkatan Produki Padi di Kecamatan Tabir Kabupaten Merangin pada Tahun 2017

\section{Karakteristik petani $\left(X_{1}\right)$ dan interaksi petani dengan penyuluh dan kelompok $\left(\mathrm{X}_{2}\right)$}

Tingkat persepsi petani tentang peranan penyuluh dalam peningkatan produksi padi $\left(\mathrm{Y}_{1}\right)$
$\mathrm{X}_{1.6 .}$ Luas penguasaan lahan
0,372
$\mathrm{X}_{2.1 .}$ Intensitas interaksi petani dengan Penyuluh

Keterangan: nyata pada taraf $\alpha=0,05$

petani terhadap peranan penyuluh dan partisipasi aktif dari petani itu sendiri. Peranan dari seorang penyuluh dapat dinilai oleh petani melalui persepsi petani binaan penyuluh tersebut dan persepsi tentunya dipengaruhi oleh berbagai faktor seperti karakteristik petani (umur, tingkat pendidikan formal, jumlah tanggungan keluarga, lama berusahatani, luas penguasaan lahan, status penguasaan lahan, dan tingkat pengetahuan petani tentang peranan penyuluh) dan interaksi petani dengan penyuluh dan kelompok (intensitas interaksi petani dengan penyuluh, dan keterlibatan dalam kelompoktani).

Pengujian variabel dalam penelitian ini menggunakan Path Analysis yang bertujuan untuk melihat pola hubungan antar variabel dengan tujuan untuk mengetahui pengaruh langsung maupun tidak langsung seperangkat variabel bebas (eksogen) terhadap variabel terikat (endogen), dengan asumsiasumsi model regresi terpusat pada data yang dianalisis berjenis data interval dan ratio, data yang dipilih secara acak (random), data yang dihubungkan berdistribusi normal, data yang dihubungkan berupa linier (Riduwan dan Kuncoro, 2013). Nilai koefisien jalur yang digunakan adalah hasil dari uji regresi linier berganda menggunakan Aplikasi SPSS (Statistical Package for the Social Science) versi 21 (Tabel 5) tanpa menyertakan variabel eksogen yang koefisien jalurnya pada pengujian pertama tidak signifikan pada alpha $<0,05$, yaitu variabel: karakteristik petani (umur, tingkat pendidikan formal, jumlah tanggungan keluarga, status penguasaan lahan, luas penguasaan lahan, dan tingkat pengetahuan petani tentang peranan penyuluh) dan interaksi petani dengan penyuluh dan kelompok (keterlibatan dalam kelompoktani) dan tingkat persepsi petani tentang peranan penyuluh dalam peningkatan produksi padi.

Program Upsus Pajale merupakan program pemerintah yang bertujuan untuk peningkatan produksi dan produktivitas padi khususnya dalam penelitian ini. Program ini bersifat top down yang pendekatan pembangunan dimana penentuan keputusan tidak menampung semua aspirasi elemen di kelompok, tetapi hanya mementingkan keputusan bagian tertentu dari kelompok. Seperti pada saat perencanaan program petani memang memberikan kritik dan saran, namun kritik dan saran tersebut belum tentu selalu dilaksanakan. Berdasarkan hal tersebut program Upsus Pajale jika dilihat berdasarkan tangga tingkatan partisipasi menurut Arnstien (1986) maka dilakukannya perencanaan hanya sebagai tokenism/sekedar justifikasi mengiyakan agar masyarakat tidak tersinggung atau merasa tidak diakui keberadaannya. Partisipasi pada tingkatan ini hanya untuk pemberitahuan/informing (sekedar pemberitahuan searah/sosialisasi), konsultasi/consultation (masyarakat didengar tetapi tidak selalu dipakai sarannya), dan penentraman/placation (saran masyarakat diterima tetapi tidak selalu dilaksanakan).

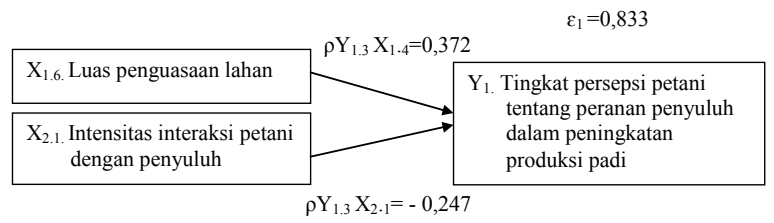

Gambar 1. Pengaruh langsung luas penguasaan lahan dan intensitas interaksi petani dengan penyuluh terhadap tingkat persepsi petani tentang peranan penyuluh dalam peningkatan produksi padi

Gambar 1 menunjukkan bahwa tingkat persepsi petani tentang peranan penyuluh dalam peningkatan produksi padi secara parsial dipengaruhi positif langsung oleh luas penguasaan lahan $(0,372)$. Hal tersebut menunjukkan bahwa petani yang semakin luas penguasaan lahannya maka tingkat persepsinya 
tentang peranan penyuluh di dalam peningkatan produksi padi akan semakin meningkat. Hal tersebut karena dengan memiliki lahan yang luas membuat petani lebih aktif sebab jika terjadi kegagalan panen petani akan mengalami kerugian yang sangat besar. Keaktifan tersebut membuat petani lebih sering bertemu dan dekat dengan penyuluh sehingga petani memiliki persepsi yang baik tentang peranan penyuluh. Menurut Mardikanto (1993) petani yang menguasai lahan sawah yang luas akan memperoleh produksi yang besar dan begitu pula sebaliknya. Hal ini sejalan dengan hasil penelitian dari Pambudy (1999) bahwa perilaku dalam berwirausaha (berusahatani) sangat berhubungan dengan besaran lahan yang dimiliki atau digunakan.

Tingkat persepsi petani tentang peranan penyuluh dalam peningkatan produksi padi secara parsial dipengaruhi positif langsung oleh intensitas interaksi petani dengan penyuluh $(0,247)$. Semakin sering intensitas interaksi petani dengan penyuluh maka tingkat persepsi petani tentang peranan penyuluh dalam peningkatan produksi padi akan semakin meningkat. Hal tersebut dikarenakan interaksi dengan penyuluh merupakan suatu hubungan yang kemudian terjalin komunikasi untuk saling bertukar informasi antara petani dan penyuluh. Wiraatmadja (1990) menyatakan bahwa dalam pelaksanaan penyuluhan, seseorang penyuluh harus saling berhubungan, hubungan tersebut pada akhirnya dapat menimbulkan komunikasi untuk dapat saling bertukar informasi. Hal ini sejalan dengan hasil penelitian dari Narso et al. (2012) bahwa faktor internal pemuda yang berpengaruh nyata terhadap persepsi tentang peranan kelompoktani dalam penanganan masalah sosial adalah interaksi dengan organisasi dan lingkungan sosial (keluarga, teman sebaya dan masyarakat), sebab dengan adanya interaksi pemuda dapat mengetahui peranan dari kelompoktani dalam menangani masalah sosial.

\section{Kesimpulan}

Tingkat persepsi petani tentang peranan penyuluh dalam peningkatan produksi padi sudah cukup baik, berarti penyuluh sudah cukup berperan dan menjalankan peranannya sesuai dengan tugas pokok dan fungsinya di dalam program Upsus Pajale untuk peningkatan produksi padi. Namun petani masih banyak yang beranggapan bahwa penyuluh dalam berkomunikasi masih dalam pendekatan individu yaitu dengan ketua kelompok dan pengurus saja, sehingga masih banyak informasi-informasi yang tidak sampai kepada anggota kelompoktani. Persepsi petani tentang peranan penyuluh dalam perencanaan Gerakan Penerapan Pengelolaan Tanaman Terpadu (GP-PTT), pelaksanakan GP-PTT, dan Percepatan Optimalsiasi Lahan (POL) berada pada kategori sedang yang berarti penyuluh sudah cukup berperan, sedangkan dalam Rehabilitasi Jaringan Irigasi Tersier (RJT) dan Penambahan Areal Tanam (PAT) berada pada kategori rendah yang berarti penyuluh masih kurang berperan, hal ini karena pada aspek RJIT tersebut adalah tugas dari Babinsa serta P3A (Perkumpulan Petani Pengguna Air) dan pada aspek PAT adalah tugas dari Babinsa.

Faktor yang berpengaruh positif secara langsung terhadap tingkat persepsi petani tentang peranan penyuluh dalam peningkatan produksi padi adalah luas penguasaan lahan dan intensitas interaksi petani dengan penyuluh. Hal tersebut karena dengan memiliki lahan yang luas membuat petani lebih aktif dan ingin memanfaatkan lahannya dengan sebaik mungkin, dan hal tersebut juga yang membuat petani lebih sering berinteraksi dengan penyuluh sehingga petani memiliki persepsi yang baik tentang peranan penyuluh di dalam peningkatan produksi padi.

\section{Daftar Pustaka}

Anggreany S, Muljono P, Sadono D. 2015. Partisipasi Petani dalam Replanting Kelapa Sawit di Provinsi Jambi. Jurnal Penyuluhan. 12(1):1-14.

Arnstein SR. 1969. A Ladder of Citizen Participation. Journal of the American Institute of Planners. 35(4):216-224.

[BPS] Badan Pusat Statistik. 2016. Sosial dan Kependudukan [internet]. [diunduh 23 Juli 2017].

Tersedia pada: https://www.bps.go.id

2014a. Proyeksi Penduduk menurut Provinsi 2010-2035 (Ribuan) [internet]. [diunduh 16 September 2016]. Tersedia pada: https://www.bps.go.id

2014b. Pola Pengeluaran dan Konsumsi Penduduk Indonesia 2014 [internet]. [diunduh 16 September 2016]. Tersedia pada: https://www.bps.go.id

Dinas Pertanian Tanaman Pangan dan Hortikultura Kabupaten Merangin. 2016. Produksi, Produktivitas, dan Luas Tanam Padi Pada Tahun 2016 di Kabupaten Merangin. Merangin (ID): Dinas Pertanian Tanaman Pangan dan Hortikultura Kabupaten Merangin.

Fauzi A, Sadono D. 2006. Persepsi dan Partisipasi 
Masyarakat Sasaran dalam Program Pengembangan Usaha Kelompok Kecil (Kasus Program Pengembangan Masyarakat PT Aneka Tambang, UPBE Pongkor di Desa Bantar Karet dan Desa Kalongliud, Kecamatan Nanggung Kabupaten Bogor, Jawa Barat). Jurnal Penyuluhan. 2(3):8-17.

[KEMENTAN] Kementrian Pertanian. 2015. Peraturan Menteri Pertanian Nomor 14/Permentan/ OT.140/3/2015 Tentang Pedoman Pengawalan dan Pendampingan Terpadu Penyuluh, Mahasiswa, dan Bintara Pembina Desa dalam Rangka Upaya Khusus Peningkatan Produksi Padi, Jagung, dan Kedelai [internet]. [diunduh 2016 November 11]. Tersedia pada: https://www.pertanian. go.id

[KEMENTAN] Kementrian Pertanian. 2016. Produksi Padi Tahun 2016 [internet]. [diunduh 2016 November 23]. Tersedia pada: https://www. pertanian. go.id

Mardikanto T. 1993. Penyuluhan Pembangunan Pertanian. Yogyakarta (ID): Sebelas Maret University Press.

Mardikanto T, Soebiato P. 2013. Pemberdayaan Masyarakat. Bandung (ID): Alfabeta.

Mosher AT. 1978. Menggerakkan dan Membangun Pertanian: Cetakan ke-6. Jakarta (ID): Yasaguna.

Muljono P. 2012. Metode Penelitian Sosial. Bogor (ID): IPB Press.

Narso, Saleh A, Asngari PS, Muljono P. 2012. Persepsi Penyuluh Pertanian Lapang tentang Perannya dalam Penyuluhan Pertanian Padi di Provinsi Banten. Jurnal Penyuluhan. 8(1):93-102.

Pambudy R. 1999. Karakteristik Personal, Prilaku Komunikasi, Perilaku Wirausaha, dan Penyuluhan dalam Sistem Agribisnis Peternak Ayam. [disertasi]. Bogor (ID): Institut Pertanian Bogor.

[RI] Republik Indonesia Undang-Undang No 16 Tahun 2006 Tentang Sistem Penyuluhan Pertanian, Perikanan dan Kehutanan.

Riana, PurnaningsihN, SatriaA. 2015. Peranan Penyuluh Swadaya dalam Mendukung Intensifikasi Kakao Di Kabupaten Sigi Provinsi Sulawesi Tengah. Jurnal Penyuluhan. 11(2):201-211.

Riduwan, Akdon. 2009. Rumus dan Data dalam Analisis Statistik. Bandung (ID): Alfabeta.

Riduwan, Kuncoro EA. 2013. Cara Mudah Menggunakan dan Memakai Path Analysis (Analisis Jalur). Bandung (ID): Alfabeta.

Rivai V, Mulyadi D. 2012. Kepemimpinan dan Prilaku Organisasi: Edisi Ketiga. Jakarta (ID): Rajawali
Press.

Sastraatmadja E. 2006. Petani di Tanah Merdeka. Bogor (ID): Petani Center HA IPB.

Unit Pelaksana Teknis Daerah Pertanian Kecamatan Tabir Kabupaten Merangin. 2014. Gambaran Umum Lokasi Penelitian dan Gambaran Umum Penyuluh Pertanian di Kecamatan Tabir. Merangin (ID): Unit Pelaksana Teknis Daerah Pertanian Kecamatan Tabir Kabupaten Merangin.

Wiraatmadja S. 1990. Pokok-Pokok Penyuluhan Pertanian. Jakarta (ID):Yasaguna. 